講座

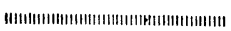

\title{
応用放射線エネルギー分析法 $(9)$
}

\section{IV. ベータ線のエネルギー分析法とその応用}

（2）固体や気体を利用したベータ線検出器 ${ }^{\dagger}$

\author{
川上宏金 \\ 東京大学原子核研究所 \\ 188 東京都田無市緑町 3-2-1
}

Key Words: silicon-detector, Compton component, scintillator, plastic scintillator, liquid scintillator, sodium iodide (thallium), anthracene, stilbene

\section{1. はじめに}

ここでは，(1)で述べた $\beta$ 線スペクトロメータ以外の 固体や気体を利用した $\beta$ 線 (電子線) 検出器について 簡単に紹介する。本論に入る前にこれらの検出器の原 理, 性能沙影を与響をる $\beta$ 線（電子）之物質の相互作 用について扣さらいをしておく。

\section{2. 電子のエネルギー損失機構}

電子は質量が陽子の1 836 分の $1\left(511.005 \mathrm{keV} / c^{2}\right)$ と 小さいため, 同じェネルギーの重い粒子に比べてェネ ルギー損失が小さく，その結果として全エネルギーを 失ない停止するまでに走る距離が長くなる。したがっ て，この過程で多くの散乱を受ける訳である。

電子が物質中を通過する時，その散乱によって原子 の励起や電離を起こし，エネルギーを失ならが，エネ ルギーが増すと原子核の強い電場の影響を受けて光子 （電磁波）を放出し，大きくェネルギーを失なう。

\section{$2 \cdot 1$ 電離や励起によるエネルギー損失}

Bethe ら ${ }^{19)}$ の計算によると入射電子が原子の励起や 電離によって失ならエネルギーは物質 $1 \mathrm{~cm}$ 当たり次式 で与えられる。

$\dagger$ Measurement of Radiation Energy and Its Application. IV. Measurement of beta-ray energy and its application. (2) Beta-ray detectors using solids and gasses. Hirokane KAWAKAMI: Institute for Nuclear Study, University of Tokyo, Midori-cho, Tanashi-shi, Tokyo 188.

$$
\begin{aligned}
& -\frac{\mathrm{d} E}{\mathrm{~d} x}=\frac{2 \pi \mathrm{e}^{4}}{m v^{2}} n Z\left\{\log \frac{m v^{2} E}{2 I^{2}\left(1-\beta^{2}\right)}\right. \\
& \left.-\left(2 \sqrt{1-\beta^{2}}-1+\beta^{2}\right) \log 2+1-\beta^{2}\right\} \quad \mathrm{erg} / \mathrm{cm}
\end{aligned}
$$

ここで，Eは入射電子の運動ェネルギー

$m, \mathrm{e}, v$ は電子の質量, 電荷, 速度 $\beta=v / c(c$ は光速 $)$ である。

また， $Z$ 注物質の原子番号

$n$ は $1 \mathrm{~cm}^{3}$ 中の原子数

I は原子を電離するために要する平均のエネ ルギーで岁る。

電子のSi対する入射ェネルギーとエネルギー損失 $(\mathrm{d} E / \mathrm{d} x)$ の関係を図 13 亿示す。図から分かるよらに エネルギー損失注電子の静止質量の〜2 倍のところで 最低の值を示し，それから低いェネルギーになると土 ネルギー損失の式の $1 / v^{2}$ が効いて急激に損失が增大 する。これによって, 検出器中におけるェネルギー応

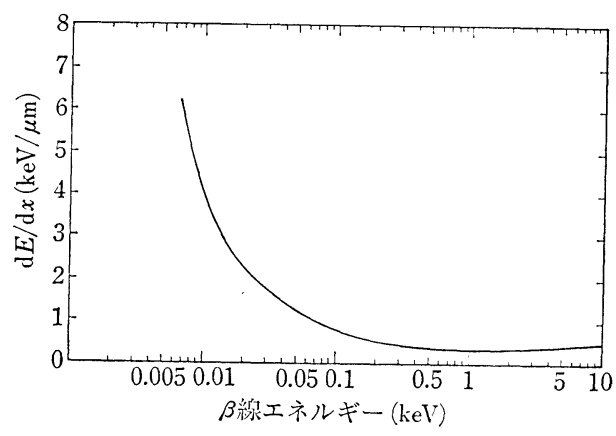

目13 Si 中での電子の入射エネルギーと エネルギー損失の関係 
答関数が決められている(3・1.6で説明)。他方, 高エ ネルギーになるとその損失は徐々に増加するだけであ る。したがって，高エネルギー電子の検出は，一般に $\mathrm{d} E / \mathrm{d} x$ を利用することが多い。

\section{$2 \cdot 2$ 輻射過程によるエネルギー損失}

古典電磁気理諭によると, 加速 $\alpha$ を受けた電荷は $\left(2 \mathrm{e}^{2} / 3 c^{3}\right) \alpha^{2}$ の割合で光子を放出する。これは，電子 が原子核の近傍を通過するさい，核の強いCoulomb場 によって大きな加速を受けるので電磁波の形でェネル ギーを失ならのである。この場合の加速の大きさは核 電荷 $(Z \mathrm{e})$ に比例し, 質量 $(m)$ に逆比例するから $\alpha \sim$ $Z \mathrm{e} / m$ となる。電磁波放出の割合は $\alpha^{2}$ に比例するので 結局 $Z^{2} / m^{2}$ に比例することになる。Bethe, Heitler ${ }^{20)}$ のくわしい計算によると, 高速電子が物質 $1 \mathrm{~cm}$ 当たり 失なら輻射によるエネルギー損失量は次式で与えられ る。ただし， $E_{0}$ は入射ェネルギー，Nは物質中の原子 密度, $r_{0}$ は古典電子半径である。

$$
-\left(\frac{\mathrm{d} E}{\mathrm{~d} x}\right)_{r_{0}}=-\frac{4 r_{0}^{2}}{137} Z^{2} E_{0} N \log \frac{183}{Z^{1 / 3}}
$$

すなわち, 輻射過程によるエネルギー損失は電子エ ネルギー $E_{0}$ と， $Z^{2}$ に比例する。

\section{$2 \cdot 3$ 電子の飛程}

飛程とは，粒子が物質中を通過してェネルギーが $E_{1}$ から $E_{2}$ になるまでに通る長さであるが，それはエ ネルギー損失の式を積分して得られる。すなわち,

$$
R\left(E_{1}-E_{1}\right)=\int_{E_{2}}^{E_{1}} \frac{\mathrm{d} E}{\frac{\mathrm{d} E}{\mathrm{~d} x}}
$$

で与えられる。

輻射過程が重要でないェネルギー領域における電子 の飛程は, 簡単には物質中での吸収曲線によって決め られる。図14に単一エネルギーの電子の吸収曲線を示 す。物質が厚い場合は, 傾斜の部分にほぼ直線的に減 少する部分があり, 最後は湾曲している。この直線部

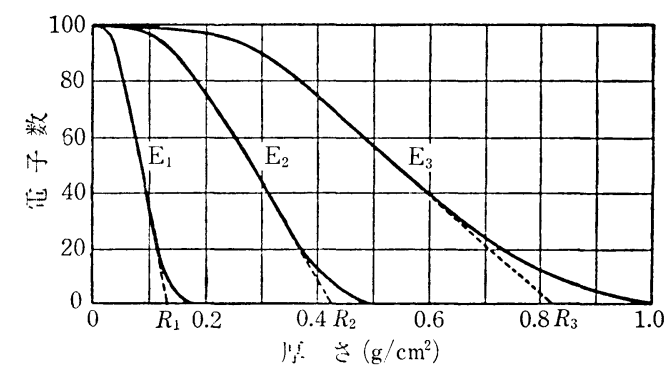

図14電子の単一エネルギーの吸収曲線

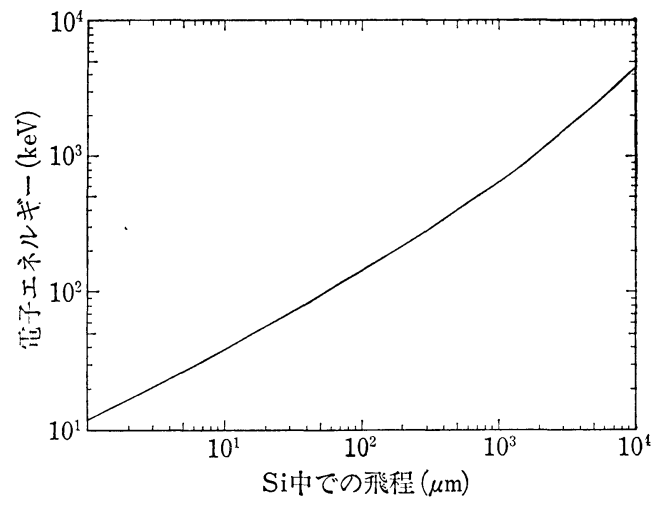

図15 Si 中の電子の飛程とエネルギーの関係 分を延長して横軸と交わる点 $R$ を電子の飛程と定義す る。Si中の飛程とエネルギーの関係を図15に示す。こ れに関して, Glendenin はつぎの実験式 ${ }^{21)}$ 導出し た。

$$
\begin{array}{ll}
R=0.407 E^{1.38} & 0.15 \mathrm{MeV}<E<0.8 \mathrm{MeV} \\
R=0.542 E-0.133 & 0.8 \mathrm{MeV}<E<3 \mathrm{MeV}
\end{array}
$$

ここで, $R$ は $\mathrm{g} / \mathrm{cm}^{2}$ で測った飛程, $E$ は $\mathrm{MeV}$ 単位 で測った值である。

\section{3. 検出器の種類とその利用法}

さて， $\beta$ 線のエネルギー分析に使われる検出器とし ては, それ自身がある程度のエネルギー分解能を持っ ているのでそのまま, または他の検出器と併用して使 われる $\mathrm{Si}$ 半導体検出器と, 既述の磁気, 電場等のスペ クトロメータで運動量やェネルギーを分析した後の計 数管として使われる気体検出器や, 最近開発されたマ イクロチャンネルプレートのようにその入射位置を同 定することにより位置感応型検出器として利用されて いるものがある。

この章では, $\mathrm{Si}$ 半導体検出器, シンチレータ, 位置 感応型検出器について説明する。

\section{$3 \cdot 1 \mathrm{Si}$ 半導体検出器}

この講座ですでにその動作原理等について詳細に述 べられているので22，ここでは応用面からみてどんな 利用の仕方があるかを紹介する。

まず, この検出器の利点としては以下の点が挙げら れる。

（1）エネルギー分解能がよい。

市販されているプレナー型検出器でも小型になる と $\sim 5 \mathrm{keV}$ の分解能 (以下, 分解能とは断りのない 限り半值幅をいう）を保証している。また個々の例 
では検出器のみならず前置増幅器初段のFET も冷 却して $2-3 \mathrm{keV}$ の高分解能のデータも報告されて いる。

（2）磁気, 電場の分析器に比べてはるかに広いェネ ルギー領域を一度に测定できる。

(3) 固体であるため電子の飛程が短くて小型であ る。

（4）薄い検出器ですむため信号の立ち上がり時間が 比較的速い。とくに, プレナー型では数 nsのものも ある。したがって, 同時計測用検出器として利用さ れる。

(5) 取り扱いが比較的簡単である。

以上の利点がある反面, 線源が $\gamma$ 線も放出している 場合は, $\gamma$ 線によるコンプトン成分 ( $\gamma$ 線の物質によ る吸収に注光電効果, コンプトン効果, 電子対生成の 三つの過程があり，その物質の原子番号 $(Z)$ 依存性 はそれぞれ $Z^{5}, Z^{1}, Z^{2}$ に比例している。したがって， $\mathrm{Si}(Z=14)$ は $\mathrm{Ge}(Z=32)$ に比べて $Z$ が低いため, 光電 効果によるピークは観測されずュンプトン成分が観測 される) がバックグラウンドとして観測される。それ を抑制する手法として以下に述べるいくつかの方法が 開発された。

$3 \cdot 1 \cdot 1$ 比例計数管 $+\mathrm{Si}$ 検出器の同時計測法による コンプトン成分の抑制

これは比例計数管 (PC) が気体を使っているため, $\gamma$ 線に対して感度が低いこと，他方 $\beta$ 線は電荷を持っ た粒子であるので感度が高いことを利用している。 $\mathrm{PC}$ と Si の信号の同時計測をとることによって, Si 信 号中の $\gamma$ 線のコンプトン信号を抑制し $S / N$ を改善し ている。図16にその構成を示す23)。PCで使っている ガスは 1 気圧の純メタンである。 ${ }^{206,207} \mathrm{Bi}$ の線源によ る結果ではコンプトン成分は〜1/1000に抑制された。 スペクトルを図17に示す。 $\mathrm{Si}(\mathrm{Li})$ 検出器自身の分解能 は $4 \mathrm{keV}$ であった。この検出器系の検出効率は 300 $\mathrm{keV}$ 以上の電子に対して $80 \%$ で一定であった。200 $\mathrm{keV}$ 以下の電子は比例計数管の膜やガス中で散乱され $\mathrm{Si}$ 検出器に入射しにくくなり, 同時計数率が急速に低 下するので使えない。

$3 \cdot 1 \cdot 2$ マグネット+Si 検出器によるコンプトン成 分抑制と内部転換電子測定

この方法は，とくに $\gamma$ 線や低ェネルギー電子線放出 の多いインビーム $\beta$ 線分光で開発されよく利用され た。世界的にもよく製作された。図18にとの典型的な 例 ${ }^{24)}$ を示す。マグネットは小型の 5 個の Co-Sm の合 金による永久磁石で構成され, 中心にある $\gamma$ 線遮蔽用

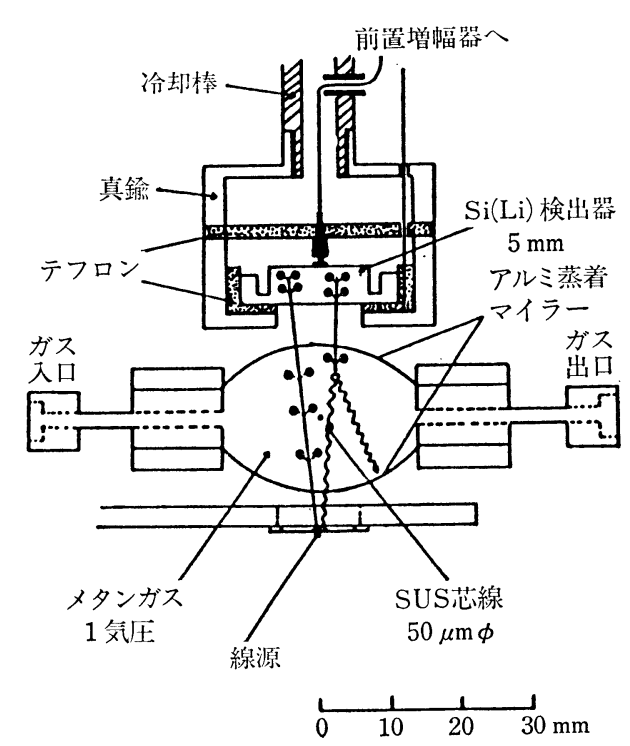

図16 $\gamma$ 線フリ一の $\mathrm{Si}(\mathrm{Li})$ 検出器系 ${ }^{23)}$ 比例計数官 $(\mathrm{PC})$ と $\mathrm{Si}(\mathrm{Li})$ 検出器でカウンター テレスコープを形成している

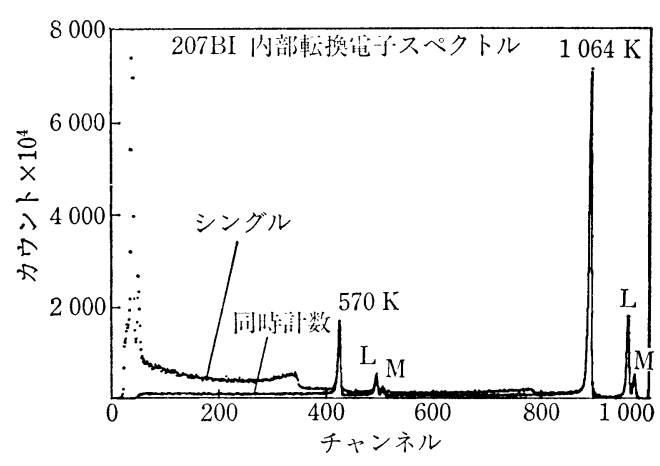

図17 $\mathrm{PC}+\mathrm{Si}$ 検出系による ${ }^{207} \mathrm{Bi}$ のスペクトル23) $\mathrm{Si}$ 検出器によるシングルスペクトルを 比較のために示してある

の $\mathrm{Pb}$ シールドの周りにオレンジのように配置されて いる(このためこのマグネットをミニオレンジとも呼 ぶ)。この永久磁石の作る磁場によって電子線の運動 量を大まかに分析, 輸送し, Si 検出器でェネルギー分 析を行う。したがって, 分解能は使用する $\mathrm{Si}$ 検出器の 性能によって決まる。この検出器系で測定した ${ }^{207} \mathrm{Bi}$ の内部転換電子スペクトルを図19に示す。シングルス ペクトルで観測されたコンプトン成分がほとんど観測 されていない。その抑制ファクタは500 keVエネルギ 一で $1 / 300,1000 \mathrm{keV}$ で $1 / 25$ であった。この系の検 出効率は図20に示す。この場合磁場の值が決まってい るので高いエネルギーの電子線の効率は徐々に低下し ている。実用的なェネルギー範囲は $200 \mathrm{keV}$ 以上であ 

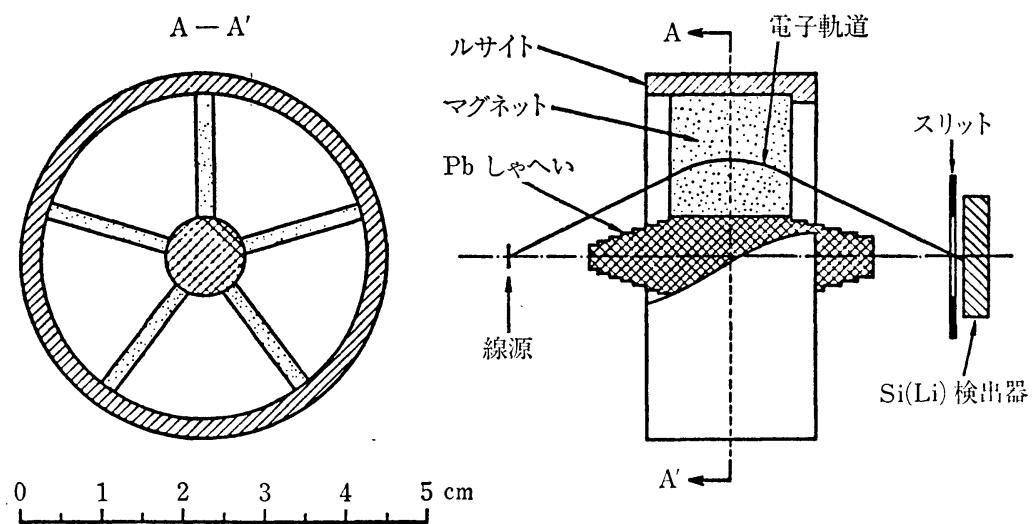

図18 マグネット+Si検出器系の構成図 ${ }^{24}$

磁石は $\mathrm{Co}-\mathrm{Sm}$ の合金による永久磁石である

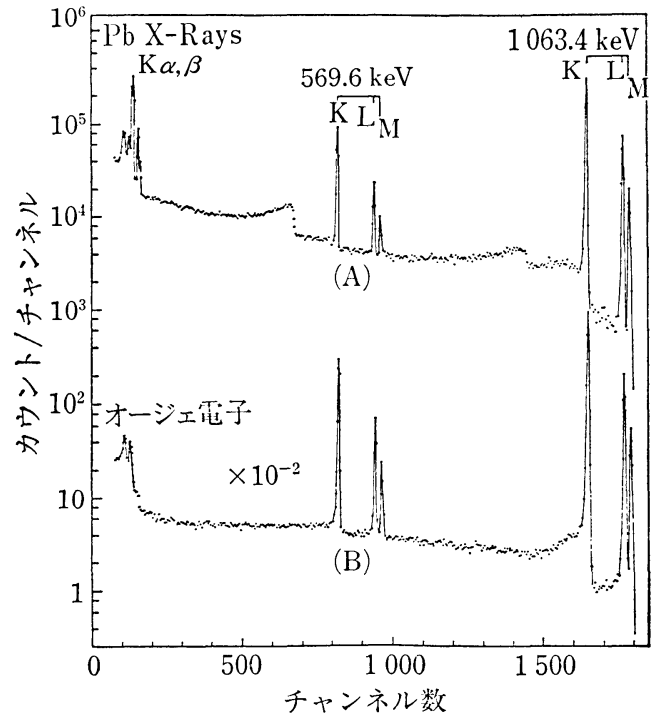

図19 マグネット+Si検出器系による ${ }^{207} \mathrm{Bi}$ の スペクトル24)

(A): $\mathrm{Si}$ のシングルスペクトル

(B): マグネット+Si 検出器系によるスベクトル

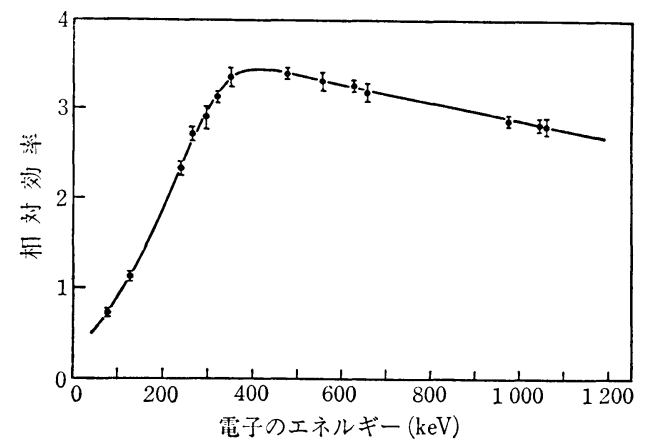

図20 マグネット+ $\mathrm{Si}$ 検出器系の検出効率24
る。

ミニオレンジ $+\mathrm{Si}$ 系は磁場の值が一定のため, たと えば，もっと低いエネルギーの電子線を効率よく測定 しようとすると，マグネットの交換が必要であるが， それを擗けるためにソレノイド電磁石で磁場を発生さ せている例もある。図21にその断面図 ${ }^{25}$ を示す。3 個 のソレノイドを使用し, 線源と $\mathrm{Si}(\mathrm{Au})$ 検出器の距離 は40 cm と，かなり離れているので， $\gamma$ 線やX線が検 出器を見込む立体角はかなり小さい。これにより $\gamma$ 線 のコンプトン成分を抑制している。他方，電子線は螺 旋運動して輸送されるので立体角はそれほど低下しな い。ただ，コイルの内径は $26 \mathrm{~mm}$ とさいので，一度 に測定できるェネルギー領域が狭いのを補らため、コ イルに流す電流を 1 分間の周期で増減させている。そ の増減の幅は最大電流の15\%である。使用した検出器

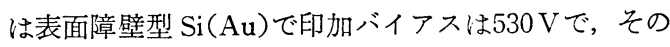
時の空乏層の厚さは1.65 mmであった。困15によると

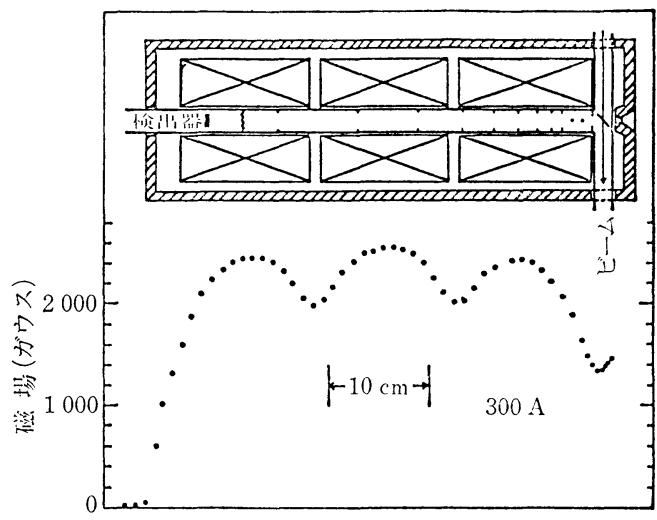

図21 ソレノイド $+\mathrm{Si}$ 検出器系の構成図 ${ }^{25)}$ 下の図は電流 $300 \mathrm{~A}$ ときの磁場分布である 


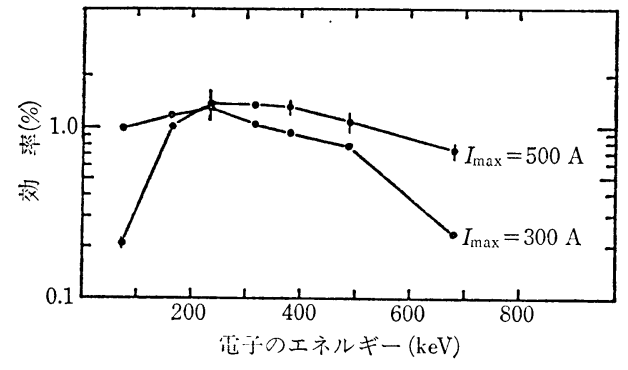

図22 ソレノイド+ $\mathrm{Si}$ 検出器系の検出効率251 最大電流 $300 \mathrm{~A}$ と $500 \mathrm{~A}$ の結果を示す

この飛程は950 keVの電子線に相当する。分解能は $630 \mathrm{keV}$ 電子に対して $2.9 \mathrm{keV}$ であった。図 22 にこの 系の検出効率を示す。磁場を換学ることにより 100 $\mathrm{keV}$ 以下の電子線でもよい効率で測定できる。このタ

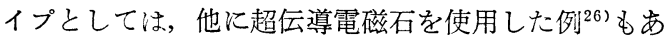
る。

$3 \cdot 1 \cdot 3 \Delta E-E$ カウンタテレスコープによるコンプ トン抑制と内部転換電子測定

コンプトン抑制の他の方法として, 大疑ら ${ }^{27)}$ の開発 した方法を紹介する。 $\Delta E$ カウンタとして市販の厚さ $150 \mu \mathrm{m}$, 表面積 $100 \mathrm{~mm}^{2}$ の $\mathrm{Si}(\mathrm{Sb})$ 検出器を, $200 \mathrm{~K}$ に冷却して使用した。エネルギー分解能は $482 \mathrm{keV} に$ 対して $4.2 \mathrm{keV}$ であった。 $E$ カウンタとしては厚さ $4 \mathrm{~mm}$, 表面積 $300 \mathrm{~mm}^{2}$ の $\mathrm{Si}(\mathrm{Li})$ 検出器を自作し,

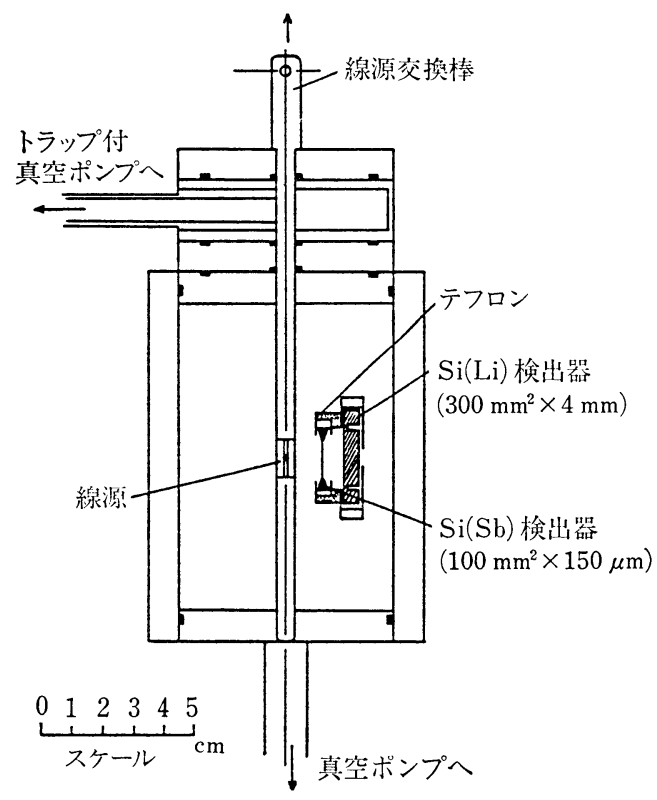

図23 $\Delta E-E$ カウンターテレスコープの構成図 ${ }^{27)}$

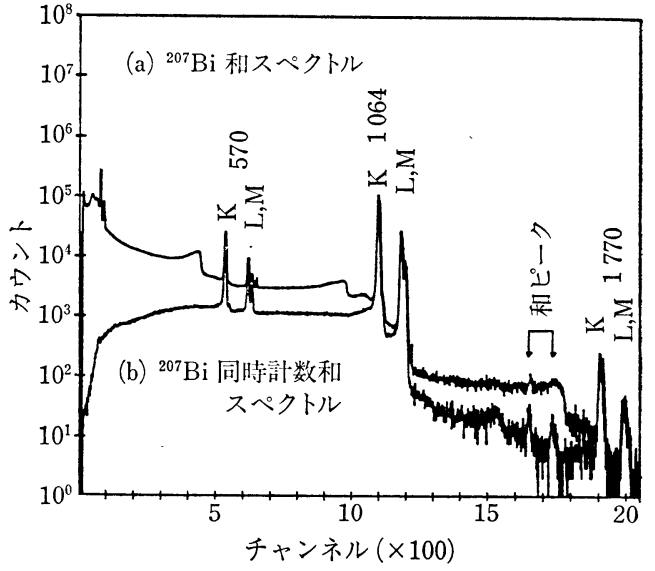

図24 $\Delta E-E$ 検出器系で測定された ${ }^{207} \mathrm{Bi}$ の スペクトル27)

(a): 単なる和スペクトル

(b): 新しい系で測定されたスペクトル

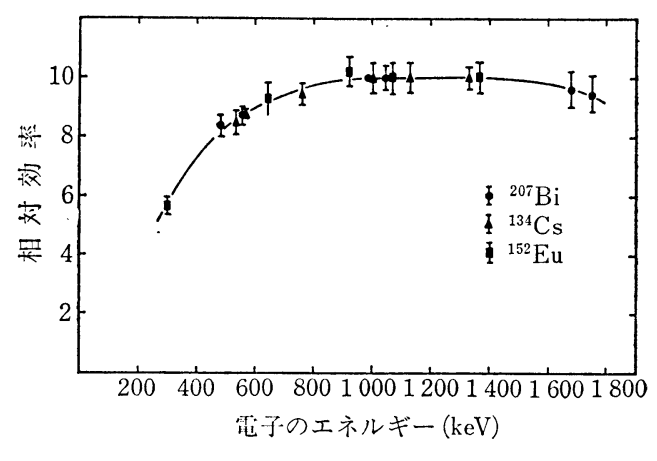

図25 $\Delta E-E$ 検出器系の相対検出効率 ${ }^{271}$

液体窒素で泠却して $2.6 \mathrm{keV}$ のエネルギー分解能を得 た。その構成は図23のようである。 $\gamma$ 線は $\Delta E$ 検出器 では感度が低いので $\Delta E$ と $E$ 検出器の信号の同時計測 和をとるとコンプトン成分の抑制されたスペクトルが 得られる。 ${ }^{207} \mathrm{Bi}$ のスペクルの例を図24に示す。(a)の 単なる和ではュンプトン成分は落ちないが，(b)の同時 計測和ではきれいに落ちているのが分かる。この系の 相対検出効率を図 25 に示す。効率のよいのは $300 \mathrm{keV}$ 以上である。

$3 \cdot 1 \cdot 4 \quad \beta-\mathrm{e}, \beta-\gamma$ 同時計测法による $\beta$ 線バックグ ラウンドの抑制と内部転換電子測定

線源から強い $\beta$ 線が放出されている環境で内部転換 電子スペクトルを測定する場合, ぞらしてもその $\beta$ 線 によって $S / N$ 覀いデータしか得られないケースが 


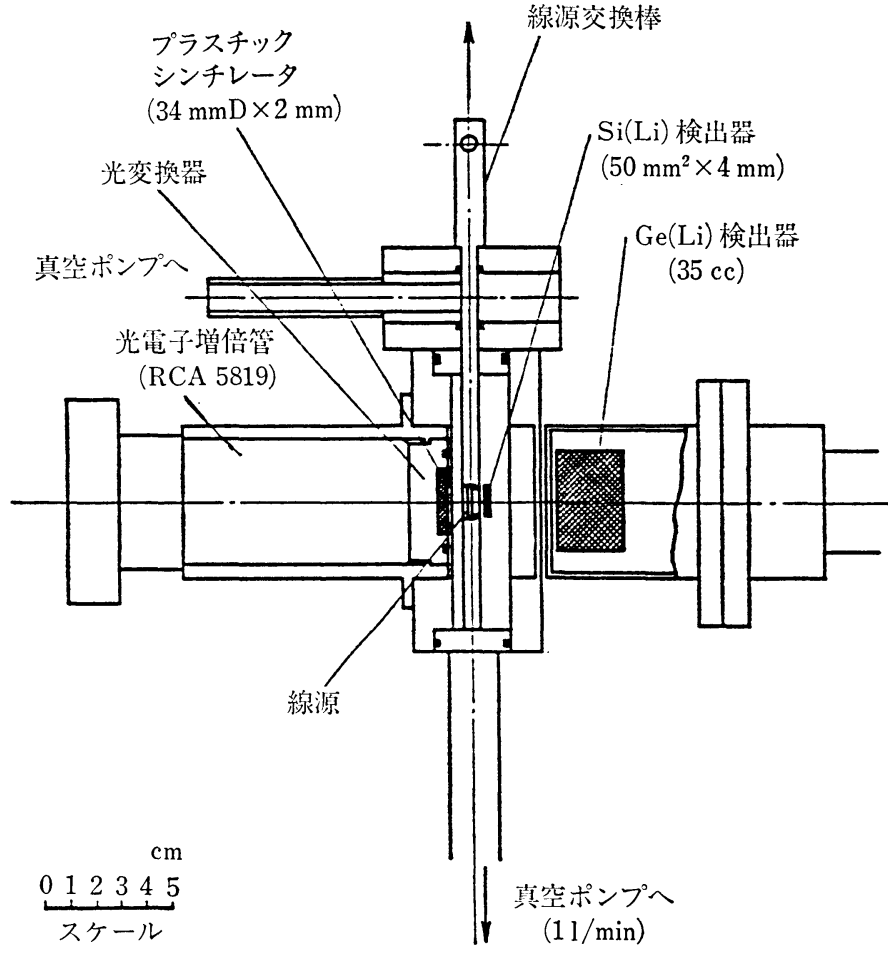

図26 $\beta-\mathrm{e}, \beta-\gamma$ 同時計数装置の構成図 ${ }^{28)}$
多い。これを改善するために開発され た装置が図26に示されている ${ }^{28)}$ (ここ では $S / N$ のい $\gamma$ 線も測定できるよ うになっている)。 $\beta$ 線をプラスチッ クシンチレータで, 内部転換電子線を $\mathrm{Si}(\mathrm{Li})$ 検出器で, $\gamma$ 線を $\mathrm{Ge}(\mathrm{Li})$ 検出 器で検出している。冷却 FET に結合 された $\mathrm{Si}(\mathrm{Li})$ 検出器を液体空素で $77 \mathrm{~K}$ に泠却して $624 \mathrm{keV}$ 電子で $2.1 \mathrm{keV}$ の 高分解能を達成した。プラスチックシ ンチレータの信号と $\mathrm{Si}(\mathrm{Li})$ と $\mathrm{Ge}(\mathrm{Li})$ の信号を同時計測して図27に示したよ うな $S / N$ の改善されたデータを得た。 ${ }^{124} \mathrm{Sb}$ の $\beta^{-}$放出核の場合で $\beta$ 線のバッ クグラウンドを $1 / 20$ に抑制した。

$3 \cdot 1 \cdot 5 \mathrm{X}$ 線との同時計測による $\beta$ 線とコンプトン成分の抑制 と内部転換電子測定

内部転換電子放出過程は引き続い て，その軌道電子の空孔を埋めるため にX線を放出する確率が高い。ところ が， 線はX線放出を伴わない。そこ で，このX線と同時計測することによ

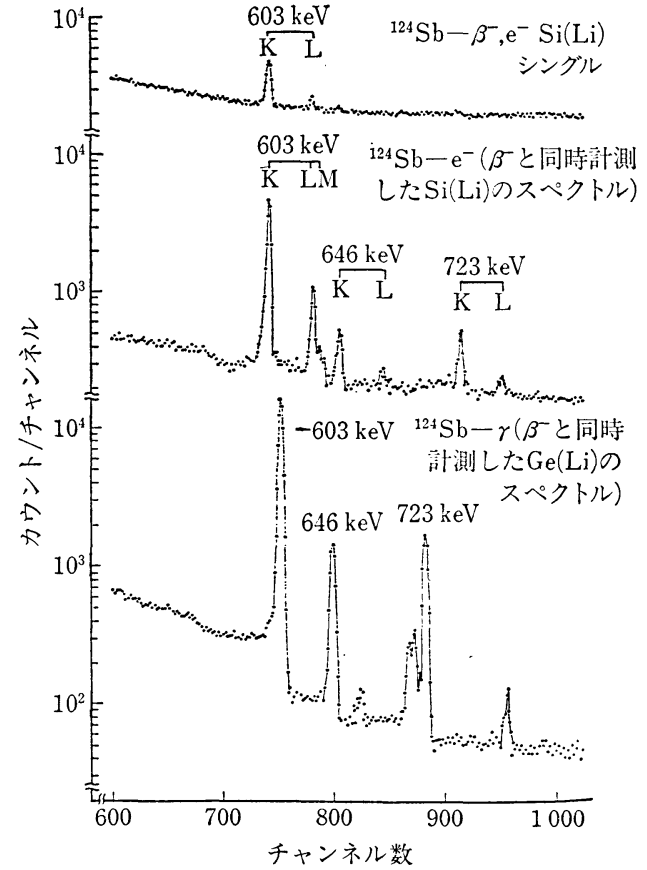

図27 $\beta-\mathrm{e}, \beta-\gamma$ 同時計数系で測定された 内部転換電子と $\gamma$ 線スペクトル28) り $\beta$ 線と $\gamma$ 線のコンプトン成分を抑制することができ る。 2 個の $\mathrm{Si}(\mathrm{Li})$ 検出器の 1 個でX線を, 他方で内部 転換電子を検出する。FETを泠却して $629 \mathrm{keV}$ 電子線 に対して $2.1 \mathrm{keV}$ の高エネルギー分解能を得た。 X線

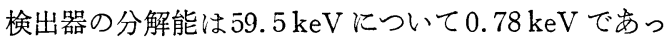
た。線源を間にして 2 個の $\mathrm{Si}(\mathrm{Li})$ 検出器をできるだけ 接近させて配置し立体角を大きくとる。この系で測定 した ${ }^{124} \mathrm{Sb}$ のスペクトルを図28に示す ${ }^{29)} \mathrm{KX}$ 線でゲー トをしているためK-内部転換電子のピークしか観測 されていない。 $\beta$ 線とコンプトンの抑制ファクタは 1/80であった。

$3 \cdot 1 \cdot 6 \quad \beta$ 線スペクトロメータ+ $\mathrm{Si}(\mathrm{Li})$ 検出器系で の自然計数率の抑制法

スペクトロメータで分析された $\beta$ 線を計数する計数 管として Si 検出器を使用する場合， $\gamma$ 線がないので $S / N$ よいデータを得られるが，入射した $\beta$ 線の一部 は表面での後方散乱によって観測スペクトルの全エネ ルギー損失ピークの下の低エネルギー領域に長い平担 なスペクトルを示す。他方, 自然計数スペクトルもピ ークをもたず比較的平らな形を示す。したがって, $S / N$ のよいデータを得るためには, 全エネルギー損失 ピークの領域のみを計数すればよい。東京大学原子核 


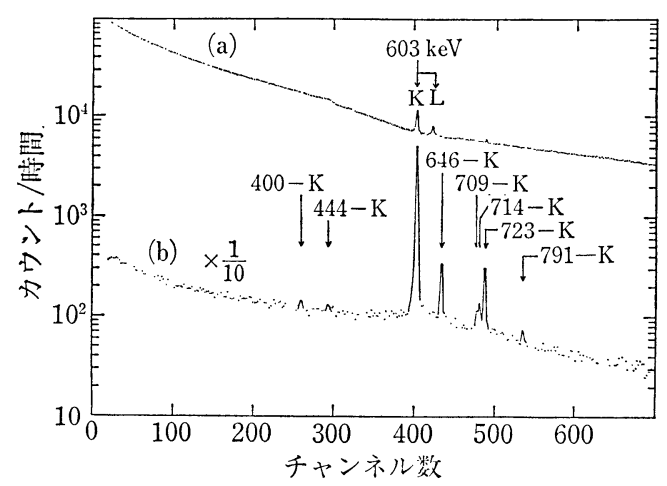

図28 X-e-同時計測スペクトル29)

(a): シングル

(b): KX 線との同時計測スペクトル
研究所（INS）の空芯 $\beta$ 線分析器での結果 ${ }^{30)}$ を紹介す る。

使用した検出器慎性領域 $2 \mathrm{~mm}$, 直径 $16 \mathrm{~mm}$ の $\mathrm{Si}$ $(\mathrm{Li})$ 検出器で, エネルギー分解能は ${ }^{207} \mathrm{Bi} の 1063 \mathrm{keV}-$ $\mathrm{K}$ で $25 \mathrm{keV}$ であった (室温で使用)。 ${ }^{90} \mathrm{Sr}$ の連続 $\beta$ 線 をスペクトロメータで分析し，200-2 $200 \mathrm{keV}$ に対す る $\mathrm{Si}(\mathrm{Li})$ 検出器での応答関数を測定した(図29)。2 $\mathrm{mm}$ 厚さの飛程に相当する電子のエネルギーは図15で分か るように $1100 \mathrm{keV}$ である。このエネルギーを超えた $1200 \mathrm{keV}$ の入射電子のスペクトルから突き抜けによ る成分 (ピークの下のこぶ，あるいは台形）が現れて いる。エネルギーが低い時は，Si 中に入射した電子の エネルギーはすべて検出器内で消費されるから全エネ ルギー損失のピークを示すが，エネルギーが高くなっ

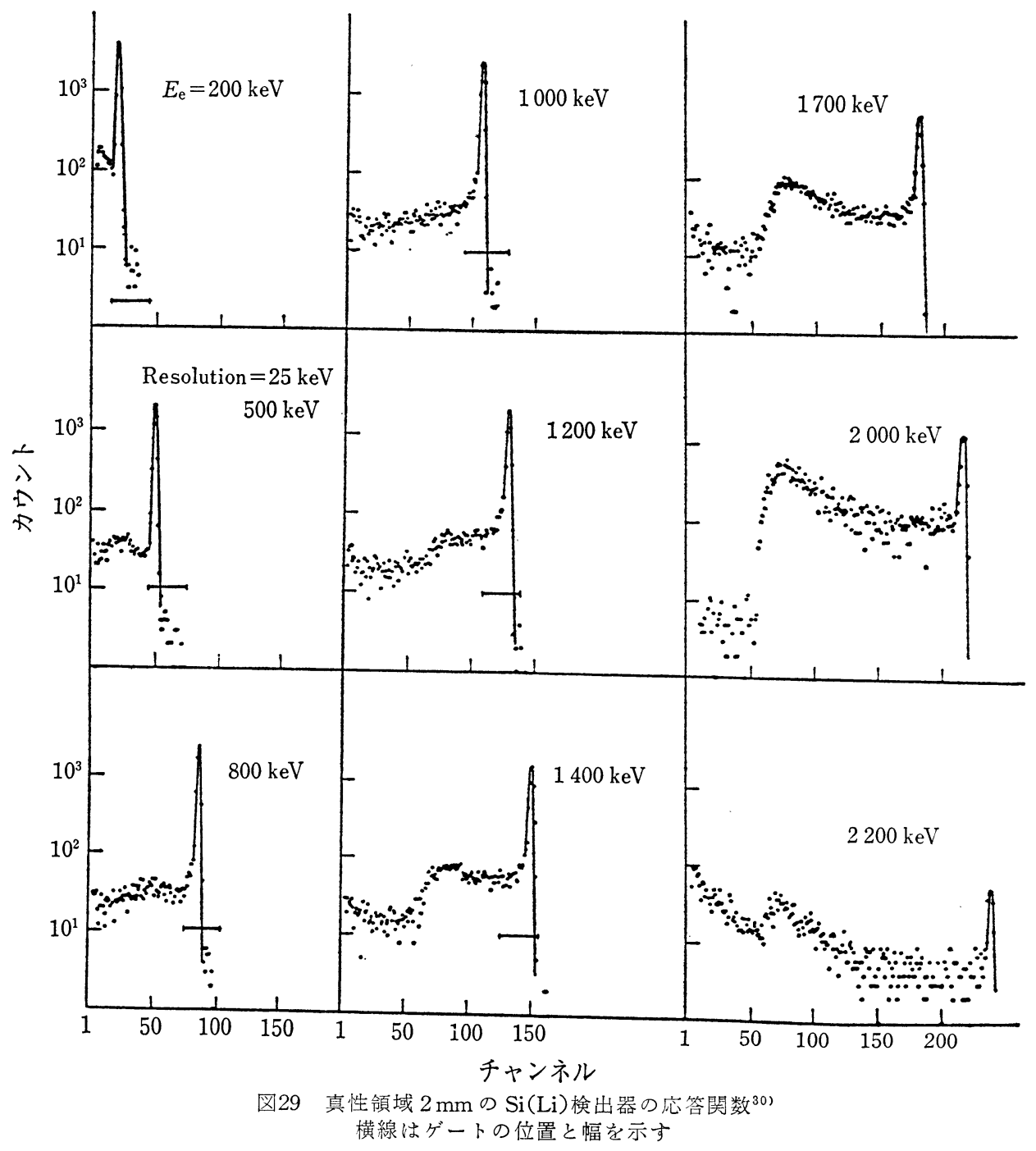


て突き抜けるようになると，その分だけ低いェネルギ 一消費しかしないし，その未消費の割合は多重散乱に よって変わるので台形のよらなスペクトルを示す。し かし，その場合でも電子は軽いため散乱によってだん だんエネルギーを失ない低いェネルギーになる。する と, 図14の $\mathrm{d} E / \mathrm{d} x$ の曲線が示すように, 低いエネル ギーではエネルギー損失がますます増大し，結局全エ ネルギーを失なう確率が比較的高くなり，ピークも観 測されるのである。

スペクトロメータのコイル電源の出力を利用して, このピークにゲートを自動的に設定できるように掃引 回路を製作した。これを計数回路系のシングルチャン ネル弁別器の低レベル設定に利用した（図29の横捧の 場所と長さにゲートを設定した)。この系での検出効率 を図30に示す。効率のよい使用領域は $150-1000 \mathrm{keV}$ である。それるで数カウントであった自然計数が 1 cpm以下に落ちた。

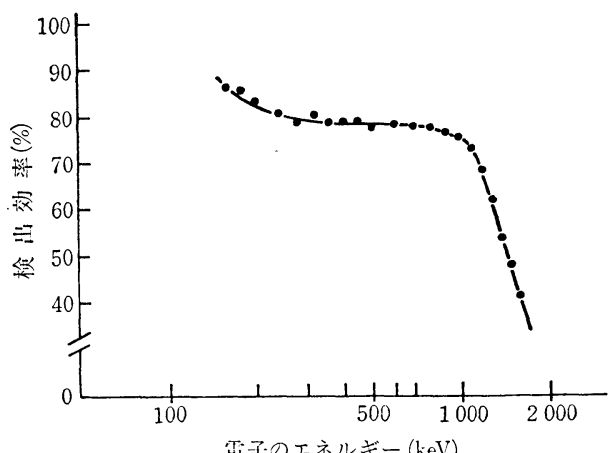

図30 自動掃引回路を使って測定した $\mathrm{Si}(\mathrm{Li})$ 検出器の検出効率30)

図 $31 V^{207} \mathrm{Bi} の 569.6 \mathrm{keV}-\mathrm{L}$ 内部の転換電子スペクト ルに対してこれまでのGM管による測定と新しい系 での測定結果の比較を示す。 $S / N$ が格段に改善されて いるのが分かる。

$3 \cdot 1 \cdot 7 \mathrm{Si}$ 半導体検出器のまとめ

すでに紹介したように，この検出器を使って $S / N$ のよいデータ収集の方法が開発されてきた。とくに, 内部転換電子測定については， $\gamma$ 線を大幅に抑制した 方法がいくつも考案され, 威力を発揮している。

市販の検出器としてはエネルギー分解能は $5 \mathrm{keV} の$ ものがあるが，もっとよい分解能のものは自作して FET 冷却して得られる。そうして得た最高の分解能 は〜2 keVである。この值は電子のエネルギーが1 000 $\mathrm{keV}$ としても， $\beta$ 線スペクトロメータの分解能の $0.1 \%$
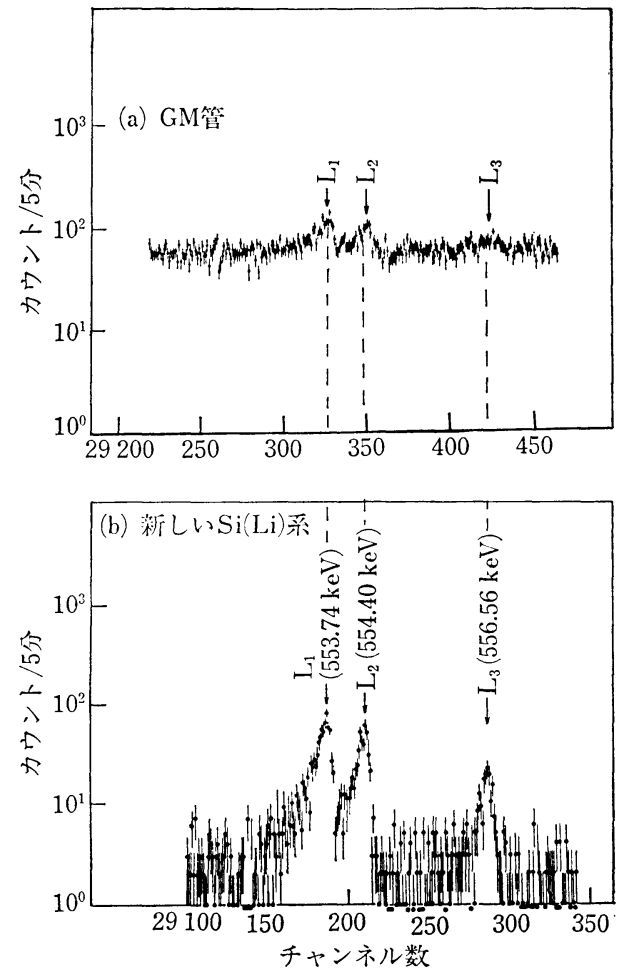

図31 ${ }^{207} \mathrm{Bi}$ の $569.6 \mathrm{keV}-\mathrm{L}$ 内部転換電子 スペクトル30)

(a)：GM管によるこれまでのスペクトル

(b): 新しい系で測定したスペクトル

の運動量分解能にしか相当しない。スペクトロメータ の分解能 $0.01 \%$ には及ばない。やはり，一度に湘定で きる領域が大きいというメリットを生かして使用すべ きであろう。とは言っても，高分解能を得るために液 体窒素で泠却するといらのは，それなりに煩わしいも のである。そこで, 室温で使用できる半導体検出器の 開発が進められてきた。それについては，Sakai ${ }^{311}$ に よるレビューがあるので詳細はそれを参照されたい。

素材としては，高いピーク/コンプトン比を与える

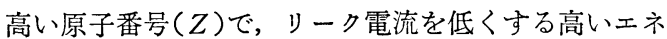
ルギーバンドギャップのものがもっぱら調べられた。 それらの中でよい分解能を得ている半導体検出器とし ては GaAs, $\mathrm{CdTe}, \mathrm{HgI}_{2}$ 結晶がある。検出器の大きさ は, まだ，断面が数 $\mathrm{mm} \times$ 数 $\mathrm{mm}$, 厚さが $2 \mathrm{~mm}$ 以下 と小さいが, $60 \mathrm{keV}$ の $\gamma$ 線に対するエネルギー分解能 は，それぞれ 0.64，1.5，1.2 $\mathrm{keV}$ と報告されている （電子線についてのテストはされていない)。このう ち, $\mathrm{CdTe}$ と $\mathrm{HgI}_{2}$ は市販されている。このレビューか ら 8 年が経過したが, 未だ有力な室温半導体検出器が 
出現しないというょうに，なかなか難しい問題がある のであろらが，いずれ開発され，電子線に対しても手 軽に使光る検出器が実現されることを期待したい。

また，測定エネルギー領域については，50 keV以下 になると雑音等の問題がありかなり困難であったが, 最近では $\mathrm{Si}$ ではないが, 高純度 $\mathrm{Ge}$ 検出器 $\left(200 \mathrm{~mm}^{2} \times\right.$ $7 \mathrm{~mm}$ 厚さ）飞， １4 MeVに加速したトリチウム線源 を执よそ $0.3 \mathrm{~mm}$ の深さにインプラントして，受けた 放射線損傷をアニールすることにより補修して，トチ リウムのエネルギースペクトルを $1 \mathrm{keV}$ を゙測定した といらデータもある ${ }^{32)}$ 。もちろん，検出器は液体窒素 で泠却し，エネルギー分解能として $310-405 \mathrm{eV}$ を得 ている。このように測定領域が低エネルギーに拡がる と，またその応用分野も払がることが期待される。

\section{$3 \cdot 2$ シンチレーション検出器}

この検出器は土ネルギー分解能が悪いかわりに, 立 体角を大きくできることから，むかしから $\beta$ 線のエネ ルギー分析によく使用されてきた。しかし，Si半導体 検出器の開発により, 最近ではその利用は低エネルギ 一 $\beta$ 線か, 特殊な実験での利用に限られてきた傾向に ある。

$\beta$ 線測定によく使われるシンチレータとしては $\mathrm{NaI}$ (Tl), アントラセン, スチルベン, 液体シンチレータ, プラスチックシンチレータがある。

この検出器の原理は, 高速荷電粒子が物質中でエネ ルギーを失なうさいにその経路に沿って多数のイオ ン，電子，励起原子を発生させる。これらのイオンが 電子と再結合するときとか, 励起原子が基底状態にも ぞるさいに，余分なエネルギーの一部を光（シンチレ ーション）として放出する。この光を光電子増倍管の 光電面に当て，その時発生する光電子を二次電子増倍 部で増幅し, 光電子の数に比例した大きさの電気的パ ルスとして取り出すわけである。

この検出器の利点として以下の点が挙げられる。

(1) パルスの分解時間が数ナノ秒と非常に短く, 計 数率の高い場合に有効である。

(2) 大容量の検出器ができるので検出効率が高く, かなり高エネルギーの $\beta$ 線にる使える。

（3）実験に合った形に製作，加工でき，さらに種類 に応じてその性能を換えることができるものもあ る。

（4）シンチレータによっては，たとえば，スチルベ ン等では荷電粒子の種類によって発光波形が異なる ので,これを利用して入射粒子の識別が可能である。

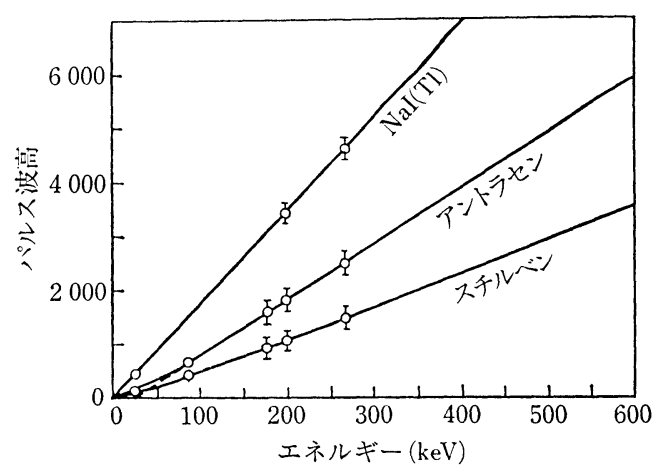

四32 シンチレータの入射エネルギーと パルス波高の関係 ${ }^{33}$

逆に欠点としては，

（1）入射荷電粒子のエネルギーと出カパルス波高値 との間にそれ汪ど充分な比例関係がないものがあ る。とくに，低エネルギーに扮いて直線からのずれ が見られる(図32)。

(2) 光電子増倍管における光電変換効率が低いた め, 光電子数のゆらぎが大きくエネルギー分解能が 悪い。

（3）光を利用しているので，検出器の入射面を光遮 蔽する必要があり，このため低エネルギーの電子線 の測定ができない場合がある。

なお，光を電気パルスに变換するための光電子増倍

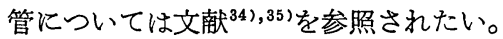

つぎに，各シンチレータについて，簡単に説明する。 $3 \cdot 2 \cdot 1 \mathrm{NaI}(\mathrm{Tl})$

ヨウ化ナトリウム $(\mathrm{NaI})$ は純粋なままでは监光効率 が悪いので，これにタリウムを微量に入れて結晶にす ると蛍光効率が大きくなる。この結晶が $\mathrm{NaI}(\mathrm{Tl})$ 検出 器である。入射荷電粒子のエネルギーと出力パルスの 比例関係は $1 \mathrm{keV}-650 \mathrm{keV}$ に対しては，完全に満たさ れている。その絶対効率は拈よそ10\%である。

この結晶は吸湿潮解性があるので取扱いに注意しな ければならない。蛍光減衰時間は $0.25 \mu \mathrm{s}$ とシンチレー タのなかでは長い。サイズとしては $12.7 \mathrm{~cm} \phi \times 10.16$ cm!の大きいるのも入手できるが，自分で任意の形に 加工できないのが難点である。 $\mathrm{Tl}(Z=81)$ といら原子 番号の大きな元素のため, $\gamma$ 線に対しても検出効率が 大きいので, $\gamma$ 線のある環境下での $\beta$ 線の測定は $S / N$ が悪く非常に難しい。

$3 \cdot 2 \cdot 2$ 有機シンチレータ(アントラセン，スチルペ ン)

有機シンチレータの大きな特長は無機結晶に比べ 
て, 蛍光減衰時間が短いということである。アントラ センは〜 30 ns, スチルベンは 3-8 ns である。構成原 子がCとHであるため， $\gamma$ 線に対する感度が低いこと は $\beta$ 線測定にとっては有利な点である。

大きな結晶は製造が難しく，アントラセンで 2.54 $\mathrm{cm} \phi \times 1.27 \mathrm{~cm}$ 厚さ以上のものは入手が困難である。 また，不純物によって蛍光効率が大きく減少する。一 般に，加工性が悪く，とくに，スチルベンは脆く，熱 にも弱いので取扱いに注意が必要である。

$3 \cdot 2 \cdot 3$ 液体シンチレータ

結晶有機シンチレータは大型のものを造るのに適当 ではない。また，適当な形に加工することも難しい。

この久点を補うのが液体シンチレータでである。 $p^{-}$ テルフェニルのような有機シンチレータをトルェンや キシレンなどの有機溶媒にとかしたものである。第二

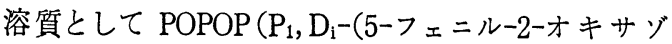
ル)ーベンゼンの略号) を加えることによって発光波長 を変換して, 光電子増倍管の感度波長に合わせてパル ス波高を大きくすることも可能である(この第二溶質 をウェーブレングスシフタともいう)。有機シンチレ 一タに比べて蛍光効率は落ちるが, 減衰時間は $2-3 \mathrm{~ns}$ とさらに短い。

ものによっては, 相当引火性が強いので取扱いには 注意が必要である。また, 溶媒の純度が悪いとパルス 波高が半減することもある。さらに，酸素が溶けてい ると蛍光効率が低下するので, 必要に応じて窒素を通 じて酸素を除く。

このシンチレータは ${ }^{3} \mathrm{H}$ ような低いエネルギー $\left({ }^{3} \mathrm{H}\right.$ の $\beta$-の最大エネルギーは $18.6 \mathrm{keV}$ である) の $\beta$ 線測 定によく使われる。それはシンチレータのなかに ${ }^{3} \mathrm{H}$ 線源を混入させて測定できるので，立体角が 100\% と高く, 非常に検出効率がよい。微弱放射線の測定 や，污染のスミア検査でもよく使われている。

$3 \cdot 2 \cdot 4$ プラスチックシンチレータ

液体シンチレータの長所を活かして，しかもその欠 点を除いたものがプラスチックシンチレータである。 溶質を溶かした固溶体で, 基幹となる物質はスチレ ン，ビニルトルェンなどである。安定で加工す容易で ある。1 $\mathrm{m}$ 以上の大きなるのもある。また，厚さ 0.03 $\mathrm{mm}$ といら薄いシート状のものもある。実験の必要に 応じて自作もできる。蛍光減衰時間は 3-5nsであり, 他の検出器との同時計測でよく使われる。

また，構成元素の原子番号が低いので， $\gamma$ 線の光電 効果によるピークは観測されないがコンプトン成分が 効率よく検出されるので, $\gamma$ 線の強い環境下での $\beta$ 線
表 2 各種シンチレータの比較35)

\begin{tabular}{|c|c|c|c|}
\hline 物 & $\begin{array}{l}\text { 相対虽光 } \\
\text { 効 } \\
(\varepsilon)^{\text {率 }}\end{array}$ & $\begin{array}{c}\text { 黨光減衰 } \\
\text { 時 } \text { 間 }^{(\tau \mathrm{ns})}\end{array}$ & $\begin{array}{c}\text { Fugure of } \\
\text { merit } \\
(\varepsilon / \tau)\end{array}$ \\
\hline $\mathrm{NaI}(\mathrm{Tl})$ & 200 & 250 & 0.80 \\
\hline アントラセン & 100 & $\sim 30^{*}$ & 3.3 \\
\hline スチルペン & $\sim 50$ & $\sim 6^{*}$ & $\sim 8.0$ \\
\hline $\begin{array}{l}\text { トルェン } \\
\text { +TP } \\
\text { +POPOP }\end{array}$ & 60 & $2-3$ & $20-30$ \\
\hline $\begin{array}{l}\text { ポリスチレン } \\
\quad+\mathrm{TP} \\
\text { +POPOP }\end{array}$ & 40 & $2-4$ & $10-20$ \\
\hline
\end{tabular}

* 早い成分の値（遅い成分は $370 \mathrm{~ns}$ に及ぶ）

の測定には，Si 検出器のような工夫が必要である。ま た，熱的に弱く夏期には自重で次第に変形することも ある。

以上のシンチレータの比較を表 2 に示した。早い計 数には液体シンチレータ（トルェン+TP+POPOP） とプラスチックシンチレータ(ポリスチレン+TP+ POPOP) が有効である。相対蛍光効率 $(\varepsilon)$ を监光減 衰時間 $(\tau)$ で割ったものを figure of meritとして比 較した。

最後に，応用面で一つの例を紹介する。シンチレー タで低いェネルギーの $\beta$ 線を測定する場合には, 光電 子増倍管の雑音等が邪魔をする場合がある。その場合 は図33に示すようなセッティングの同時計測法を採用 すると有効である。これは，雑音は主に増倍管から発

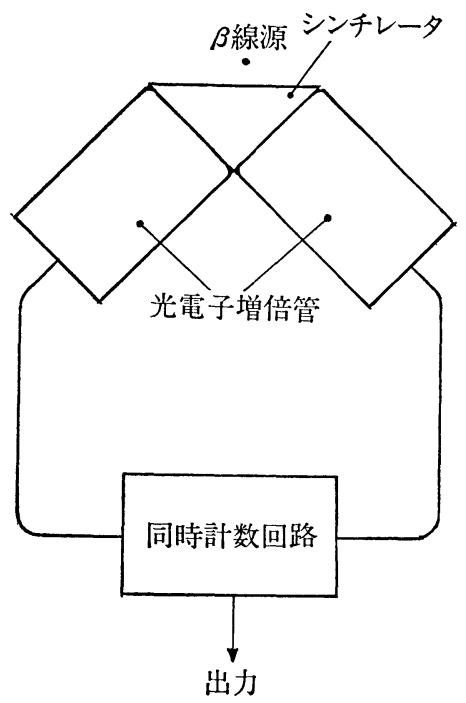

四33 シンチレータで低エネルギー $\beta$ 線を $S / N$ よく測定する場合の方法例 
生しているが, 二つの増倍管の雑音信号は同時計数し ないが， $\beta$ 線の信号は同時計数するから，雑音をかな り抑制できるからである。

雑音レベルを抑制する他の方法として考えられるこ とは, 光電子増倍管を冷却して発生している熱雑音を 抑制することである。こうすることによって, エネル ギーの低い $\beta$ 線の測定も可能になり, それによって応 用範囲が扗がることが期待される。

\section{文献}

19) Bethe, H.A.: Handbuch der Phys., 24, 519 (1933); Zeit. für Phys., 76, 293 (1934)

20) Bethe, H.A. and Heitler, W.: Proc. Roy, Soc., A146, 83 (1934)

21) Glendenin, L.E.: Nucleonics, 2, 12 (1948)

22）渡辺 鐶: Radioisotopes, 38, 485 (1989)

23) Toriyama, T., Nishio, T., Kanbe, M. and Hisatake, K.: Proc. of the International Conf. on Future Directions in Studies of Nuclei Far from Stability, Nashville, Tennessee, September 10-13, p. 97-102 (1979)

24) Ishii, M.: Nucl. Instr. \& Meth., 127, 53 (1975)
25）高木 望, 黑柳登喜太 : 原子核研究, 21, 495508 (1976)

26) Anderson, V. and Christensen, C.J.: Nucl. Instr. \& Meth., 61, 77 (1968)

27) Ohya, S., Muturo, N. and Furusawa, A.: ibid., 196, 169 (1982)

28) Ohya, S. Tamura, T. and Matumoto, Z. ibid., 101, 121 (1972)

29) Ishi, M.: ibid., 93, 271 (1971)

30）藤田雄三, 川上宏金, 大矢 進 : 原子核研究, 21, 466-482 (1976)

31) Sakai, E.: Nucl. Instr. \& Meth., 196, 121 (1982)

32) Hime, A. and Simpson, J.J.: Phys. Rev., 39D, 1837 (1989)

33) Taylor, C.J., Jentschke, W.K., Remley, M.E., Eby, F.S. and Kruger, P.G.: ibid., 84, 1034 (1951)

34）窪田信三（近角聡信等編集）: “放射線”, p. 237 共立出版, 東京 (1973)

35）三浦 功，菅 浩一，俣野恒夫 : “放射線計測 学”, p. 75, 裳華房, 東京 (1976) 